\title{
Analysis on the Efficiency of Tourism Poverty Alleviation in Hubei Province*
}

\author{
Xiaoyan Huang \\ Hubei Business College \\ Wuhan, China \\ Zhongnan University of Economics and Law \\ Wuhan, China 430074
}

\author{
Liping $\mathrm{Hu}$ \\ Hubei Business College \\ Wuhan, China
}

\begin{abstract}
Tourism poverty alleviation, as the main mode of industrial poverty alleviation, has the characteristics and advantages of strong "hematopoietic function", wide participation of poor people, low production and operation costs, and good poverty alleviation effect. Through the construction of the DEA model, the empirical analysis of the poverty alleviation efficiency of cities (states) in Hubei Province from 2010 to 2016 and the analysis of the Malmquist index is carried out. The conclusions are as follows: The comprehensive efficiency of tourism poverty alleviation in cities (states) of Hubei Province is low, mainly due to scale efficiency. The stock of tourism resources is limited, the level of industrial factors is low, and attention should be paid to the expansion of human resources. The Malmquist productivity index of tourism poverty alleviation in Hubei Province has certain regional aggregation, and space spillover effects and heterogeneity have appeared. It is necessary to pay attention to coordinate the development of regional tourism economy, improve the efficiency of tourism poverty alleviation, and implement tourism precision poverty alleviation.
\end{abstract}

Keywords-tourism poverty alleviation efficiency; scale efficiency; Malmquist index; precision poverty alleviation

\section{INTRODUCTION}

The positive and ecological nature of tourism determines that the tourism industry plays a pivotal role in China's economic transformation and upgrading and poverty alleviation. It plays a significant role in driving poverty alleviation, improving local ecological environment and promoting high-quality development of regional economy. The UK's Department for International Development (DFID) (1999) emphasizes that tourism poverty alleviation is a net benefit and development opportunity for the poor through the development of tourism. Xiang Yanping et al. (2012) believe that tourism poverty alleviation refers to a poverty alleviation method that vigorously develops tourism industry in poverty-stricken areas, which promotes regional economic development through tourism, and makes the local poverty alleviation. Qiu Xinyan et al. (2013) believe that tourism poverty alleviation refers to the development of a tourism

*Project: Humanities and Social Sciences Research Project of Hubei Provincial Education Department: Dynamic Evolution of Tourism Poverty Alleviation Efficiency in Hubei Province (18G137). economy by developing rich tourism resources in povertystricken areas, making tourism a regional pillar industry, and realizing a regional economic model in which povertystricken populations and local finances both get rid of poverty and become rich.

Throughout the research literature on the efficiency of tourism poverty alleviation at home and abroad, most scholars have adopted the DEA method, which has carried out a lot of research mainly from the aspects of the evolution of time and space pattern and the analysis of influencing factors. Efficiency research methods mainly include stochastic frontier analysis (SFA) and data envelopment analysis (DEA). The SFA method is a parametric model. It is generally necessary to determine the functional relationship between variables in advance. The DEA method is a nonparametric model. There is no need to set the functional relationship between the input and output indicators in advance, which can avoid the mistakes caused by subjective factors, and can also decompose the efficiency. Therefore, this paper selects the DEA method and combines with the Malmquist productivity index to decompose and analyze the nature of the change.

\section{RESEARCH METHOD}

The DEA (Data Envelopment Analysis, DEA) data envelopment analysis method is a method for evaluating the relative effectiveness between departments in 1978 by the famous operations researchers A. Charnes, WW Cooper and E. Rhodes. By inputting multiple inputs and multiple output data, the mathematical efficiency model is used to find the boundary efficiency points, and the data envelope line is formed accordingly. It mainly includes comprehensive efficiency, pure technical efficiency and scale efficiency. Tourism poverty alleviation efficiency refers to the efficiency of local tourism industry development or scale agglomeration efficiency. Pure technical efficiency indicates the measurement of the efficiency of tourism investment allocation for tourism poverty alleviation under the certain level of tourism poverty alleviation technology. Scale efficiency refers to the difference between the existing scale and the optimal scale of tourism poverty alleviation investment under the premise of the existing tourism poverty alleviation policy and the technical level of tourism talents, 
reflecting the rational allocation of the input and output factors of tourism poverty alleviation efficiency.

The DEA model mainly includes the CCR model with the same scale return and the BCC model with variable scale return. Considering the analysis of pure technical efficiency and scale efficiency is more conducive to the analysis of the specific reasons for DEA invalidity, this paper adopts the BCC model.

$$
\begin{aligned}
& \min \theta, \theta_{\text {is unlimited }} \\
& \operatorname{s.t}\left\{\begin{array}{c}
\sum_{j=1}^{n} \lambda_{x_{i j}}+S_{i}^{-}=\theta x_{i 0} \\
\sum_{j=1}^{n} \lambda_{j} y_{r j}-S_{r}^{+}=y_{r 0} \\
\lambda_{j} \geq 0, j=1,2, \cdots n, S_{i}^{-} \geq 0, S_{r}^{+} \geq 0
\end{array}\right.
\end{aligned}
$$

In the formula, the $\mathrm{i}$ type of input of the jth decision unit $D M U_{j}$ is $X_{i j}$; the $\mathrm{r}$ type of output is ${ }^{y_{j j}} ;{ }^{X_{i 0}}$ and $y_{r 0}$ are the

$$
\begin{aligned}
m_{V, 0}\left(y_{t+1}, x_{t+1}, y_{t}, x_{t}\right)= & \frac{d_{v}^{t+1}\left(x_{t+1}, y_{t+1}\right)}{d_{V}^{t}\left(x_{t}, y_{t}\right)} \times\left[\frac{d_{V}^{t}\left(x_{t}, y_{t}\right)}{d_{0}^{t}\left(x_{t}, y_{t}\right)} / \frac{d_{v}^{t+1}\left(x_{t+1}, y_{t+1}\right)}{d_{0}^{t}\left(x_{t+1}, y_{t+1}\right)}\right] \\
& \times\left[\frac{d_{0}^{t}\left(x_{t+1}, y_{t+1}\right)}{d_{0}^{t+1}\left(x_{t+1}, y_{t+1}\right)} \times \frac{d_{0}^{t}\left(x_{t}, y_{t}\right)}{d_{0}^{t+1}\left(x_{t}, y_{t}\right)}\right]^{1 / 2}
\end{aligned}
$$

\section{Tfp $=$ Eff $\times$ Tech $=P e \times$ Se $\times$ Tech}

If the Tfp index is greater than 1 , it indicates that the total factor productivity level is increased; if the Tfp index is less than 1 , indicating that the total factor productivity is reduced; a certain change ratio constituting the index is greater than 1 , indicating that it is the source of the increase in the level of production efficiency; and if it is less than 1 , it is the source of the decrease in the level of production efficiency.

\section{EMPIRICAL ANALYSIS}

\section{A. Indicator System and Data Sources}

Using the DEA model to measure the poverty alleviation efficiency of tourism in Hubei Province, it is necessary to scientifically and rationally select the input and output indicators: the total Chinese tourism revenue and the total number of Chinese tourism can better reflect the local tourism level, and the per capita GDP can representatively reflect the local economy. The per capita net income of rural residents and the per capita disposable income of urban residents can better reflect the income and living standards of local residents. The main purpose of tourism poverty alleviation is to promote the development of local economy and the improvement of local residents' income and living input and output values corresponding to $D M U U_{j 0} ; \theta_{\text {is the }}$ target value; $\lambda_{j}$ is the decision variable; $\mathrm{S}_{i}^{-}$and $\mathrm{S}_{i}^{+}$are the slack variables of input and output, respectively.

Among them, when $\theta \in[0,1]$, when $\theta=1, \mathrm{~S}_{i=0}^{+}$and $\mathrm{S}_{i}^{-}=0$, the DMU is relatively effective; when $\theta=1, \mathrm{~S}_{i \neq 0}^{+}$ or $\mathrm{S}_{i}^{-} \neq 0$, DMU is weakly valid; when $\theta<1$, DMU is not valid.

Since the BCC model can only measure cross-section data and measure the panel data, in 1982, Caves et al. proposed the Malmquist productivity index. In order to compare the changes of DMU productivity in different periods, Fare et al. combined it with DEA to measure the growth of total factor productivity (Tfp) in 1994. The total factor productivity (Tfp) index can be decomposed into the technical efficiency change (Eff) index and the technological progress (Tech) index. The technical efficiency change (Eff) index can be further divided into pure technical efficiency change $(\mathrm{Pe})$ and scale efficiency change $(\mathrm{Se})$ index. 


\section{B. Results and Analysis}

1) Overall evaluation of tourism poverty alleviation efficiency in Hubei province:

The average efficiency of tourism poverty alleviation in various cities (states) in Hubei Province was 0.382 in 2010,
0.425 in 2013 , and 0.362 in 2016 . Overall, it was relatively stable; the average technical efficiency average was 0.964 in $2010,0.930$ in 2013, and 0.937 in 2016. The level is generally high and stable; the average efficiency of scale is 0.393 in 2010, 0.273 in 2013, and 0.193 in 2016, and the level is generally low and showing a downward trend.

TABle I. Detailed Value of Tourism Poverty Alleviation EFFiciency in Various Cities (States) OF Hubei Province

\begin{tabular}{|c|c|c|c|c|c|c|c|c|c|c|c|c|}
\hline & \multicolumn{4}{|c|}{2010} & \multicolumn{4}{|c|}{2013} & \multicolumn{4}{|c|}{2016} \\
\hline & crste & vrste & scale & trend & crste & vrste & scale & trend & crste & vrste & scale & trend \\
\hline Wuhan & 0.050 & 1.000 & 0.050 & drs & 0.042 & 1.000 & 0.042 & drs & 0.037 & 1.000 & 0.037 & drs \\
\hline Huangshi & 0.372 & 1.000 & 0.372 & drs & 0.660 & 1.000 & 0.660 & drs & 0.474 & 1.000 & 0.474 & drs \\
\hline Shiyan & 0.207 & 1.000 & 0.207 & drs & 0.168 & 0.802 & 0.209 & drs & 0.138 & 0.841 & 0.164 & drs \\
\hline Yichang & 0.197 & 0.998 & 0.197 & drs & 0.187 & 1.000 & 0.187 & drs & 0.122 & 1.000 & 0.122 & drs \\
\hline Xiangyang & 0.202 & 0.943 & 0.214 & drs & 0.221 & 0.923 & 0.240 & drs & 0.186 & 0.983 & 0.189 & drs \\
\hline Ezhou & 1.000 & 1.000 & 1.000 & - & 1.000 & 1.000 & 1.000 & - & 1.000 & 1.000 & 1.000 & - \\
\hline Jingmen & \begin{tabular}{|l}
0.383 \\
\end{tabular} & 1.000 & 0.383 & drs & 0.476 & 1.000 & 0.476 & drs & 0.385 & 1.000 & 0.385 & drs \\
\hline Xiaogan & \begin{tabular}{|l|}
0.344 \\
\end{tabular} & 0.965 & 0.356 & drs & 0.437 & 0.932 & 0.469 & drs & 0.394 & 0.950 & 0.415 & drs \\
\hline Jingzhou & 0.314 & 0.959 & 0.328 & drs & 0.361 & 0.934 & 0.386 & drs & 0.267 & 0.944 & 0.282 & drs \\
\hline Huanggang & 0.353 & 0.992 & 0.356 & drs & 0.447 & 0.861 & 0.520 & drs & 0.305 & 0.829 & 0.368 & drs \\
\hline Xianning & 0.231 & 0.903 & 0.255 & drs & 0.279 & 0.865 & 0.323 & drs & 0.200 & 0.866 & 0.231 & drs \\
\hline Suizhou & 0.488 & 1.000 & 0.488 & drs & 0.462 & 0.936 & 0.493 & drs & 0.401 & 0.903 & 0.444 & drs \\
\hline Enshi & 0.212 & 0.733 & 0.289 & drs & 0.208 & 0.764 & 0.273 & drs & 0.153 & 0.795 & 0.193 & drs \\
\hline Shennongjia & 1.000 & 1.000 & 1.000 & - & 1.000 & 1.000 & 1.000 & - & 1.000 & 1.000 & 1.000 & - \\
\hline mean & 0.382 & 0.964 & 0.393 & & 0.425 & 0.930 & 0.448 & & 0.362 & 0.937 & 0.379 & \\
\hline
\end{tabular}

a. crste - comprehensive efficiency, vrste - pure technical efficiency, scale-scale efficiency

b. - indicates that the scale returns are fixed; drs indicates that the scale returns are declining; and irs indicates that the scale returns are increasing.

It can be seen from "Table I" that the efficiency values of Ezhou and Shennongjia Forest Area are all 1 in three years. DEA is effective, and the scale returns are the same, indicating that the tourism development of these two regions has a significant impact on the income of local people, and the tourism poverty alleviation efficiency is the highest. Tourism has the best effect on poverty alleviation; cities such as Huangshi, Suizhou and Shiyan are relatively reasonable, while others are relatively low. In addition to the relatively low technical efficiency of several cities such as Enshi, the pure technical efficiency of other regions is generally high, indicating that the development of tourism industry is good, the rational allocation of resource elements and industrial factors is strong, the level of tourism management is high, and tourism development It has significantly improved the income level of local people and reduced poverty. However, the scale efficiency is generally low, and the scale is decreasing, indicating that the level of tourism resources and industrial factors available for development in cities (states) of Hubei province is relatively low, while the tourism poverty alleviation efficiency is low and the effect is poor.

2) Analysis of the results of the Malmquist total factor productivity index for tourism poverty alleviation in Hubei province: In 2010-2016, the average factor productivity index of tourism poverty alleviation in Hubei Province was 0.913 , that is, the overall annual average decreased by $8.7 \%$. The average value of technical efficiency change index was 0.978. The average value of technological progress index was 0.933 , and the average value of pure technical efficiency change index was 0.995 . The average efficiency change index of scale efficiency is 0.983 .
TABLE II. RESULTS OF THE MALMQUIST TOTAL FACTOR PRODUCTIVITY INDEX FOR TOURISM POVERTY ALLEVIATION IN HUBEI PROVINCE

\begin{tabular}{|l|l|l|c|c|c|}
\hline \multicolumn{1}{|c|}{ firm } & effch & techch & pech & sech & tfpch \\
\hline Wuhan & 0.952 & 0.996 & 1.000 & 0.952 & 0.948 \\
\hline Huangshi & 1.041 & 0.900 & 1.000 & 1.041 & 0.937 \\
\hline Shiyan & 0.934 & 0.936 & 0.972 & 0.962 & 0.875 \\
\hline Yichang & 0.924 & 0.962 & 1.000 & 0.924 & 0.889 \\
\hline Xiangyang & 0.986 & 0.941 & 1.007 & 0.979 & 0.928 \\
\hline Ezhou & 1.000 & 0.971 & 1.000 & 1.000 & 0.971 \\
\hline Jingmen & 1.001 & 0.925 & 1.000 & 1.001 & 0.926 \\
\hline Xiaogan & 1.023 & 0.929 & 0.997 & 1.026 & 0.951 \\
\hline Jingzhou & 0.973 & 0.938 & 0.997 & 0.975 & 0.913 \\
\hline Huanggang & 0.976 & 0.915 & 0.970 & 1.005 & 0.892 \\
\hline Xianning & 0.977 & 0.922 & 0.993 & 0.983 & 0.901 \\
\hline Suizhou & 0.968 & 0.948 & 0.983 & 0.984 & 0.917 \\
\hline Enshi & 0.948 & 0.907 & 1.014 & 0.935 & 0.859 \\
\hline Shennongjia & 1.000 & 0.875 & 1.000 & 1.000 & 0.875 \\
\hline mean & 0.978 & 0.933 & 0.995 & 0.983 & 0.913 \\
\hline
\end{tabular}

It can be seen from "Table II" that the total factor productivity indices of 14 cities (states) in Hubei province are all less than 1, indicating a downward trend, with Ezhou being the highest, decreased by only $2.9 \%$, while Enshi has the largest decline, decreased by $14.1 \%$. The technical progress index of each city (state) is basically close. Except for the pure technical efficiency change index of 6 cities such as Wuhan and Shiyan, the other cities are higher than 1, indicating that the tourism resources of each city (state) in Hubei province are properly allocated. The combination of the two causes the technical efficiency change index to be less than 1 except for five cities (states) such as Huangshi, indicating that there is still room for deepening the tourism poverty alleviation efficiency in Hubei province. 


\section{CONCLUSIONS AND SUGGESTIONS}

\section{A. Main Conclusions}

Using the data on tourism poverty alleviation among 14 cities (states) in Hubei Province from 2010 to 2016, the DEA-Malmquist model was constructed to measure the comprehensive efficiency and total factor productivity of tourism poverty alleviation in Hubei Province. The results show that:

- The overall level of tourism poverty alleviation in Hubei province is low. The overall efficiency of tourism poverty alleviation in Hubei province is around 0.4 , but it is relatively stable. The pure technical efficiency is generally close to 1 , indicating that the tourism resources allocation in Hubei province is reasonable, and the scale efficiency is generally low, indicating that the stock of tourism resources and the level of industrial factors are low.

- The mean value of Malmquist's total factor productivity index for tourism poverty alleviation in Hubei Province is less than 1 , indicating that tourism poverty alleviation efficiency in Hubei Province is generally decreasing; all city (state) tourism poverty alleviation Malmquist index is less than 1, but tourism poverty alleviation efficiency is high and low. However, there are certain geographical features in the high-value and low-value areas of tourism poverty alleviation, that is, there are accumulation areas, indicating spatial spillover effects and spatial heterogeneity.

\section{B. Policy Recommendations}

As an important pillar of green economy development, tourism industry plays an irreplaceable role in stabilizing growth and promoting employment. Hubei tourism poverty alleviation should seize the opportunity of the development of the Yangtze River Economic Belt, develop the inclusive tourism industry, reduce the poverty rate, and continuously improve tourism poverty alleviation effect.

1) Moderately expanding the scale of tourism development: The allocation of tourism resources in Hubei province is relatively reasonable, and the scale of tourism poverty alleviation is generally low. It is necessary to actively explore tourism resources, promote humanities and tourism resources, and raise the level of industrial factors. The accumulation of turnover is qualitative improvement.

2) Implementing tourism precision poverty alleviation: The level of tourism resource allocation in Hubei province is already high, but the poverty alleviation efficiency is not ideal. The rich are richer and the poor are poorer. Therefore, it will be of great significance to pay attention to accurately identify the poor, and the tourism resources development dividend must be tilted to the poor households to truly achieve poverty alleviation.

3) Coordinating the development of regional tourism economy: There are spatial spillover effects and spatial heterogeneity in tourism poverty alleviation efficiency in Hubei province. Therefore, it is necessary to pay attention to the regional differentiation of tourism development, change the single-handedness for regional coordinated development, enhance the efficiency of local tourism poverty alleviation and benefit other regions, and ultimately achieve the overall improvement of tourism poverty alleviation effect in the province.

\section{REFERENCES}

[1] Yan Huili, Wang Qiang, Xiong Hao, Xu Fan, Research on the Measurement of Tourism Poverty Alleviation Efficiency and Its Spatial-Temporal Evolution in Hainan's Ethnic Minority Areas [J] China Soft Science, 2018 (08): 63 - 76. (in Chinese)

[2] Yang Guangming, Yang Hang, Yang Xuecheng, Study on Spatial and Temporal Performance of Tourism Poverty Alleviation in Three Gorges Reservoir Area [J] Resource Development \& Market, 2018 , 34 (06): $868-872+888$. (in Chinese)

[3] Sun Chunlei, Zhang Mingshan, Research on the Efficiency of Tourism-aided Poverty Alleviation in the Context of Accurate Poverty Alleviation - Taking the Dabie Mountain Area of Hubei as an Example [J] China Soft Science, 2018 (04): 65 - 73. (in Chinese) 